TABLE II. - Continued.

\begin{tabular}{|c|c|c|c|c|c|c|c|c|c|}
\hline Time. & 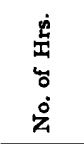 & 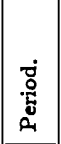 & Condition. &  & 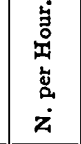 & 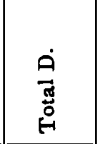 & $\begin{array}{l}\dot{\Xi} \\
\dot{0} \\
\dot{4} \\
\dot{\Delta} \\
\dot{0} \\
\dot{\theta}\end{array}$ & $\begin{array}{l}\dot{z} \\
\ddot{a}\end{array}$ & Remarks. \\
\hline $\begin{array}{c}\text { April 17, 1909. } \\
\text { 8:40 A. M.-3:40 P. M. } \\
\text { 3:40 P. M.-8:40 A. M. } \\
\text { April 19, } 1909 .\end{array}$ & $\begin{array}{r}7: 00 \\
17: 00\end{array}$ & $\begin{array}{r}\text { V. } \\
\text { VI. }\end{array}$ & $\begin{array}{l}\text { Phlorhizin. } \\
\text { Adrenalin and } \\
\text { phlorhizin. } \\
\text { Death of dog. }\end{array}$ & $\begin{array}{l}2.973 \\
6.687\end{array}$ & $\mid \begin{array}{l}0.426 \\
0.393\end{array}$ & $\begin{array}{r}9.264 \\
21.824\end{array}$ & $\begin{array}{l}\mathbf{1} .323 \\
\mathbf{1} .28\end{array}$ & $\begin{array}{l}3.116 \\
3.26\end{array}$ & $\begin{array}{l}\text { At } 3: 40 \text { P. M. } \\
\text { injected } 0.005 \\
\text { gm. of adren. } \\
\text { alin. }\end{array}$ \\
\hline
\end{tabular}

This animal was treated in a similar manner to Dog No. 5, but, because the April night was not as cold as the night of March, the dog was not sufficiently chilled to exhaust it of all its glycogen. The first administration of adrenalin was therefore followed by a rise in the $\mathrm{D}: \mathrm{N}$ ratio, showing that a sweeping out of the carbohydrates of the tissues took place. The second and third administration of adrenalin, however, failed to produce any extra sugar elimination.

These experiments show very clearly that adrenalin has not the power of converting fat into dextrose.

$$
6(4 \mathrm{I} 6)
$$

\title{
A method for the determination of small quantities of iodine in organic material.
}

\section{By ANDREW HUNTER.}

\section{[From the Department of Physiology, Biochemistry and Pharma- cology, Cornell University Medical College, Ithaca.]}

The estimation of iodine in thyroid gland and similar material is usually carried out by the method of Baumann or one or other of its various modifications. All varieties of the method have for their basal operation the quantitative conversion of the organically combined iodine into hydriodic acid. For the investigation reported by Simpson and myself I have worked out a method which rests upon a different principle altogether.

By a procedure which involves, first, the oxidation of the material with a mixture of saltpeter and potassium sodium carbonate, and, second, the action of an excess of chlorine upon the 
Relations Between Thyroid and Pituitary Glands. i I

acidified solution of the product, the iodine occurring in animal tissues may be quantitatively converted into iodic acid. After the excess chlorine has been removed, addition of potassium iodide leads to the liberation of exactly six times the original amount of iodine. The iodine thus set free may be titrated directly with a sodium thiosulphate solution of suitable strength. It is claimed for the method that it excels the various forms of the Baumann method, not only in cleanliness, convenience, and rapidity, but also in accuracy. Details will be published as soon as a larger series of control analyses is completed.

\section{7 (4I7)}

Relations between the thyroid and pituitary glands.

By SUTHERLAND SIMPSON and ANDREW HUNTER.

[From the Department of Physiology, Biochemistry and Pharmacology of the Cornell University Medical College, Ithaca, $N . Y$.]

Recent work by Herring ${ }^{1}$ has shown that complete removal of the thyroid in rabbits, cats and dogs is followed by definite histological changes in the pituitary body. A greatly increased production of colloid material by the cells of the pars intermedia was indicated. Accumulations of colloid were observed in the nervous portion of the posterior lobe and in the laminæ forming the floor of the third ventricle whence it appeared to find its way between the ependyma cells into the infundibular recess and brain ventricles.

It is believed by many that the iodine-containing substance - the so-called iodothyrin or thyroiodin - is the active substance of the thyroid gland. Reid Hunt states that the physiological activity of the thyroid varies directly with the percentage of iodine which it contains. According to Baumann, Halliburton ${ }^{2}$ and others the pituitary yields no iodine. Gideon Wells, ${ }^{3}$ from an analysis of fourteen normal human pituitaries, found an average amount of 0.0036 milligram of iodine for each gland - about one fiftieth of the quantity found in the thyroid. Ox pituitary obtained from Armour and Co. tested by Hunter's method gave no

\footnotetext{
1 Quart. Jour. of Exper. Physiol., 1908, i, 28r.

2 Quart, Jour. of Exper. Physiol., r $909, \mathrm{ii}, 229$.

3 Jour. of the American Med. Assoc., I897, xxix, 897, 954, 1007.
} 